\title{
The power of the fish is in the water
}

\author{
African, Shona saying
}

\section{Author: \\ Theo H Veldsman ${ }^{1}$ \\ Affiliation: \\ ${ }^{1}$ Department of Industrial Psychology and People Management, Faculty of Management, University of Johannesburg, South Africa}

\section{Correspondence to:}

Theo H Veldsman

Email:

theov@uj.ac.za

DOI:

10.15249/9-1-113

\section{Keywords:}

corporate social responsibility; embedded corporate social responsibility; peripheral corporate social responsibility; emerging countries

\section{Abstract}

Every organisation ("the fish") is embedded in a certain setting ("the water"). These metaphors imply a highly reciprocal, interdependent relationship between the organisation and its setting. The purpose of my article is to explore the utility of the conceptual distinction drawn by Aguinis and Glavas (2013) between Embedded and Peripheral Corporate Social Responsibility (CSR), as applied from an emerging countries (ECs) perspective. Firstly, I elucidate unique EC organisational/ people features. Secondly, I highlight the implications of these features for CSR. Finally, I address "contextually fit" CSR, arguing that Embedded CSR is the sole imperative for organisations in ECs, but as an active, societal transformation partner.

\section{Introduction}

Every organisation - the metaphorical "fish" - is embedded in a certain setting, its strategically chosen operating arena - the metaphorical "water" (cf. also Stone et al., 2013). The metaphors of "fish" and "water" imply a highly reciprocal, interdependent relationship between the organisation and its operating arena. This is even more so in emerging countries (ECs), for reasons that will be discussed below. It can be posited that the embeddedness of the organisation in its context is not and cannot be under contention: separated from life-giving "water", no organisation is viable or sustainable. Inversely, organisations, as the "fish", enhance or destroy the quality of the "water", which, in turn, affects them, constructively or destructively. The water not only must enable them to survive, but, more importantly, enable them to thrive in a sustainable way. The power of the fish truly is in the water. The organisation 
and its context, therefore, cannot be split into artificial silos, either conceptually or practically (Delios, 2010; Stone et al., 2013; Visser, 2011). Furthermore, the organisational context is multi-dimensional in nature, with each dimension representing different stakeholders. This implies that Corporate Social Responsibility (CSR) interventions are multi-dimensional by their very nature and impact (Broomes, 2013; Dobers \& Halme, 2012; Pless et al., 2012).

The above implies that CSR, in principle, also has to be fully infused in the way in which an organisation conducts its business, since the organisation and its context are inseparable, organically and systemically. Only the particular stance that an organisation's leadership wishes to adopt with respect to the organisation's embeddedness, as expressed in its chosen CSR stance and consequential CSR approach, can be critically debated (cf. Kitzmueller \& Shimshack, 2012; Pless et al., 2012). For the purpose of my article, CSR is defined as an organisation acting in an ethical, responsible, and sustainable manner in its intentions, decisions, actions, and impact towards its context, with the commensurate stakeholders, now and going into the future, for upcoming generations (cf. Aguinis, 2011; Graafland et al., 2012; Kitzmueller \& Shimshack, 2012; Visser, 2011). Put more succinctly: there is an expectation that organisations will be responsible for and towards society (Gond \& Moon, 2012).

The immediate, critical insight gained from the above vantage point is that the CSR stance adopted by an organisation, i.e. the extent to which the organisation infuses CSR into its very being, as well as its approach thereto and implementation thereof strategically, tactically, and operationally - is a leadership task and choice (Matthews, 2014; Van Marrewijk \& Hardjono, 2003). This is especially true since CSR has become a mainstream organisational activity (Basu \& Palazzo, 2008; Gond \& Moon, 2012; Kitzmueller \& Shimshack, 2012; The Economist, 2008).

The exercise of this leadership choice is a function of the responsibility orientations of leaders (Pless et al., 2012), how they make sense of CSR (Basu \& Palazzo, 2008), and their motives with CSR (Graafland et al., 2012). The debate whether the participation of an organisation in CSR is a voluntary organisational choice or an externally legally enforced activity (cf. ABländer, 2011; Broomes, 2013; Büchner, 2012; Okoye, 2012) will not be discussed here. My article will assume the former position, predominantly accepted in the CSR literature. It will also assume the fifth stage of CSR evolution, the stage of responsibility (Visser, 2011).

The purpose of my article is to explore the utility of the conceptual distinction drawn and utilised by Aguinis and Glavas (2013) between Embedded and Peripheral CSR, expressing the possible CRS stances that can be adopted by organisational leadership, from, specifically, an EC perspective. According to these authors (ibid), Embedded CSR pertains to CSR that infuses all an organisation's decisions and actions, similar to the departure point of my article (see Visser, 2011, for a similar point of view). Peripheral CSR encompasses superficial, ad hoc, and incidental CSR initiatives by an organisation.

Why the EC perspective? Increasingly, ECs are becoming the chosen operating arena for many global (or globalising) organisations as they engage with the future, given the 
predicted, growing dominance and influence of ECs in coming years in a globalising world and global economy (Rajak, 2011). Typically, ECs are countries in a state of rapid transition and fundamental transformation; are undergoing high economic growth, in absolute and relative terms to developed economies; are experiencing an increasing, tighter integration of their localised, closed economies and societies into the global village; and are benefiting from the significant influx of high levels of foreign investment (Blas \& England, 2014; Chironga et al., 2011; Ernst \& Young, 2009; Sachs, 2011; Guillén \& García-Canal, 2013; The Economist, 2010; 2011). In many quarters, the BRICS countries (Brazil, Russia, India, and China and, more recently, South Africa) are regarded as the pre-eminent representation of ECs. Within a global context, Africa is seen as the rising continent and the new frontier: seven of the ten fastest-growing economies are in Africa (Moghalu, 2014). Recently, another grouping of ECs, titled MINT - Mexico, India, Nigeria, and Turkey - was created. An EC perspective on CSR is also sorely needed because of limited research available on CSR in ECs. CSR debates and discussions to date have been dominated by European and US perspectives and interests, to the exclusion of ECs (Dobers \& Halme, 2012).

My article will proceed as follows: firstly, I will elucidate the unique features of ECs from an organisational and a people perspective. Building on these features, secondly, I will elucidate the implications of these EC features for CSR, and will conclude by addressing "contextually fit" (or relevant) CSR for organisations desiring to enter or currently operating in ECs. From the above, it should be clear that my approach to the article is an organisational leadership view.

\section{The Unique Features of ECS from an Organisational and People Perspective}

Against the backdrop of a newly emerging world order requiring organisations to rethink their business radically, in the present and for the future (cf. Ernst \& Young, 2009; IBM Global Business Services, 2008; Moghalu, 2014; Schwartz \& DiMarzio, 2011; Veldsman, 2008), what are the unique, interacting features of ECs from an organisational and a people perspective? For the purpose of my article, at least six critical, interdependent features of ECs can be distinguished that are of crucial importance for organisations that have chosen ECs as their operating arena (cf. Veldsman, 2013, from which a discussion of these features was sourced, though extended). For at least the foreseeable future, it can be argued that these features will, to a greater or lesser extent, remain characteristic of ECs as a collective, although to different degrees for individual ECs.

\section{Feature 1: A fundamental, normative transformation is occurring in ECs}

In terms of societal layers, as depicted in Figure 1, the foundational norms, values, beliefs, and assumptions informing ECs' societies (Layer 1, Figure 1) - in short, existing EC world views - are being challenged and transformed (and need to be challenged and transformed) in fundamental ways (Moghalu, 2014), resulting in intense ideological 
debates and fiercely defended divides. This transformation is accompanied by unstable power relationships and even rampant violence, with the commensurate risk of societal implosion. Some examples in this regard are: intense debates, demonstrations, and agitations about a socialist vs. a capitalist economic system; privatisation vs. nationalisation; the role of the state in the economy; a single, state-endorsed religious belief system vs. multiple religions; and the acceptance or not of the rule of law.
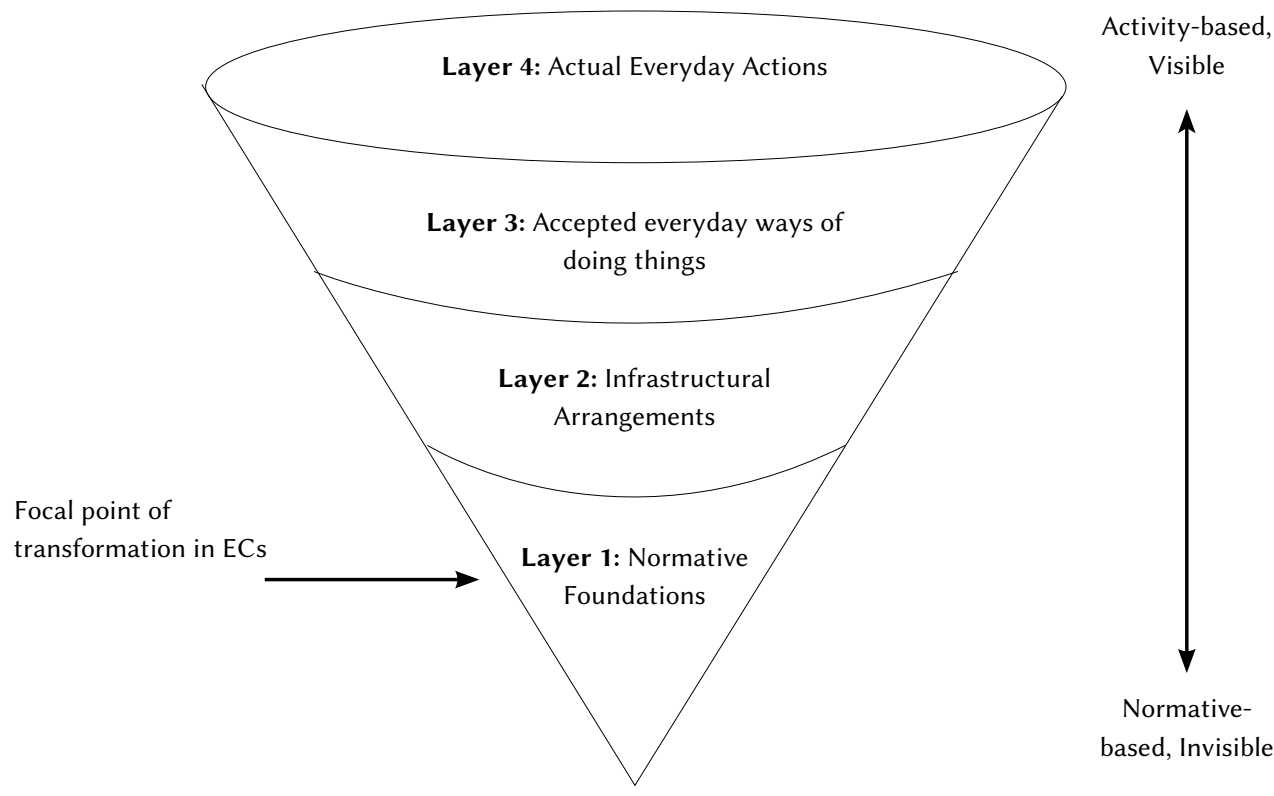

Fig. 1: The societal layers and focal point of transformation in ECs (Source: Veldsman, 2013)

In a snowballing, destabilising manner, this transformation affects society's structural arrangements (e.g. legislative/regulatory arrangements) (Layer 2, Figure 1); their accepted everyday ways of doing things (e.g. market competition rules and regulations) (Layer 3, Figure 1); and, ultimately, actual, everyday actions (Layer 4, Figure 1) (Agbakoba, 2004; Bernstein, 2010; Geldenhuys \& Veldsman, 2010; Thirlwall, 2011). This normative, foundational ambiguity and fluidity also provide fertile ground for corruption and fraud to germinate, flourish, and become endemic (Dobers \& Halme, 2012; Iheriohanma, 2011; Moghalu, 2014).

\section{Feature 2: The lead/lag development of infrastructure, with the commensurate incongruences and the absence of synergies across the country's infrastructure}

In EC societies, people and organisations do not "work together and talk to each other", or appear not to. One has to work around situations and inadequate (and/or deteriorating) infrastructure (Layer 2, Figure 1) to get things done (Layers 3 and 4, Figure 1). Alternatively, one has to use one's "contacts" to expedite decisions and actions (Dobers \& Halme, 2012; Guillén \& García-Canal, 2013; Moghalu, 2014); e.g. the economy requiring skills that the 
educational system cannot supply or can only supply in insufficient numbers; a poor transport system to meet rapidly growing traffic volumes; unstable electricity supplies to meet expanding energy demands; dysfunctional state and local authorities, requiring expeditors or middlemen to get things approved and processed; and the population growth being too high relative to the growth rate of the economy, consequently creating vast pools of unemployed or under-employed workers.

Typically, in ECs, a limited pool of high-level skills exists alongside a vast pool of semiskilled and unskilled workers, the latter battling to find and retain meaningful, longterm employment because their skills are mismatched to employment opportunities, or too few opportunities exist. This situation gives rise to socio-economic class divides and significant income disparities that are fiercely contested as being unfair and discriminatory (see also Feature 6, below) (Chironga et al., 2011; Dobers \& Halme, 2012; Thirlwall, 2011; Ukpere, 2011). Consequently, in ECs, a highly active informal economic sector exists parallel to the formal economy, as an escape valve for the high percentage of unemployed/semi-employed to earn an income.

The supply of high-level skills in ECs is also often detrimentally affected by a drain of top talent, given the global war for talent, particularly if an EC's economy is struggling to expand, offers limited attractive career prospects, and/or the quality of life in that country is poor (Benedict \& Ukpere, 2012; Doh et al., 2011; Moghalu, 2014; Ready et al., 2008; Shah, 2011). This trend may be somewhat countered where strong, home-grown, aspiring multi-national companies are emerging in an EC (Guillén \& García-Canal, 2013).

\section{Feature 3: Sophisticated technology pockets in a sea of poor/ outdated technology}

Typically, ECs have an uneven mix of technologies, with different levels of sophistication, e.g. the widespread use of mobile phone technology in semi-industrialised/agricultural societies. ECs frequently leapfrog developed countries on the technology innovation curve by immediately moving to more advanced technologies, especially regarding information/communication technology by, e.g. bypassing fixed-line communication and directly adopting the use of mobile phones and, increasingly, even smart phones (Moghalu, 2014; Sachs, 2011; The Economist, 2010, 2011).

ECs are often the suppliers of a variety of critical, non-beneficiated, natural resources to developed countries who control/own the downstream beneficiation, the so-called "curse of natural resources" of ECs (Moghalu, 2014). No or little local beneficiation occurs, which keeps EC societies at a low level of economic development, because they are unable to move down the value chain for various reasons, like the need for big technology investments in downstream beneficiation, a lack of skills, and poor economies of scale (Chironga et al., 2011; The Economist, 2011; Thirlwall, 2011). In some cases, upcoming companies in ECs serve as outsourced manufacturing/service sites, providing the subcomponents and/or products or services to organisations in developed countries, because of lower labour costs. 
Concurrently, there is a growing emergence of home-grown, aspiring multi-national companies in ECs that are increasingly engaging in the design, production, and marketing of products/services to markets in developed countries, as well as the design and production of "frugal" technological innovations more suitable to ECs. These innovations are now also starting to enter developed economies (Sachs, 2011; The Economist, 2010; Thirlwall, 2011; Thite et al., 2012).

\section{Feature 4: The dominant presence of multi-national/global, capital-strong companies in ECs}

Frequently, the relatively unsophisticated economies of ECs are dominated by the presence of multi-national/global, capital-strong companies (or their local agents), to the detriment of local, upcoming, poorly capitalised companies unable to compete on an equal footing (Broomes, 2013). Even international institutions like the International Monetary Fund, the World Bank, and the World Trade Organisation have been set up and function in accordance with mandates and rules that favour developed countries over ECs (Moghalu, 2014). This poses a real threat to the continued existence of local organisations, with a negative knock-on effect on local communities and individuals if they do fail. Often, this real or perceived threat detrimentally affects the image, reputation and legitimacy of multinational/global companies. They are seen as profiteering exploiters "raping" these countries for their own narrow, parochial interests that exclude EC-based organisations in the countries in which they operate (Moghalu, 2014; Thite et al., 2012).

Local communities may also openly and aggressively mobilise and agitate against the presence of such companies or their products/services in their country (Bernstein, 2010; Geldenhuys \& Veldsman, 2010). A case in point is the South African government's and unions' resistance to acquisition of the SA company Massmart by the USA-based global organisation Walmart. This situation is worsened if the multinational/global organisation with a physical presence in the EC country has an ethnocentric attitude - "As a global organisation, we know best, and, by the way, local is inferior" - instead of a geocentric attitude - "Every culture and person represented in our organisation carries equal weight, must be treated with respect, and can be learned from" (Perlmutter, 1969; Thite et al., 2012).

\section{Feature 5: A young, highly unemployed population, coupled with a severe drain of top talent}

Demographically, there is a large, young, unemployed population in ECs. Often, close to $50 \%$ of the population is between the ages of 15 and 30 (Chironga et al., 2011; Moghalu, 2014; Smit, 2011; Thirlwall, 2011). Simultaneously, a severe drain of top talent occurs from ECs to developed countries, as mentioned above, inter alia because of the aging demographics of the latter (Benedict \& Ukpere, 2012; Ernst \& Young, 2009; Moghalu, 2014; The Economist, 2011). This trend is countered in instances where strong, local (multi-) national companies are rising in ECs, and/or attractive entrepreneurial opportunities exist that are able to lure local talent employed in developed countries back to ECs (Benedict \& Ukpere, 2012; Doh et al., 2011; Ernst \& Young, 2009; Guillén \& García-Canal, 2013; Iheriohanma, 2011; The Economist, 2010). 
The gap in ECs between the haves and the have-nots, the latter being in the majority, creates severe ideological, socio-cultural, economic and political tensions and divides. Usually, the have-nots feel marginalised, exploited and alienated. They see no positive future for themselves. Have-nots often do not have the knowledge or skills, resources, or opportunities to aspire to and realise a better future for themselves and their dependants (Geldenhuys \& Veldsman, 2010; Smit, 2011; Thirlwall, 2011; Ukpere, 2011). The severity of the ideological debates and divides in ECs are intensified exponentially if these become institutionalised societal fault lines, socio-economically and politically, along which the haves and the have-nots are divided, and the latter then mobilises. All of the above are worsened if corruption and fraud become endemic as the acceptable way of doing things in order to enrich oneself at the expense of others, especially where public money is involved (Iheriohanma, 2011). Accusations and manifestations of "fat cats", "the gravy train" and "tenderpreneurs" grow in frequency.

The severity of the socio-cultural and economic tensions and divides may be alleviated and countered somewhat, however, if an EC is expanding aggressively because of a high growth rate; if a vibrant and strong entrepreneurial spirit and ample entrepreneurial opportunities exist and are encouraged by the powers that be; and if there is a fastgrowing middle class that many can aspire to join, alongside the emergence of rapidly expanding, resilient EC-based (multi-)national companies that offer ample attractive employment opportunities (Chironga, et al., 2011; Ernst \& Young, 2009; Guillén \& GarcíaCanal, 2013; The Economist, 2010; 2011; Thite et al., 2012).

In summary, ECs are characterised by: (i) the occurrence of fundamental normative transformations in ECs, resulting intense ideological debates and fiercely defended divides, worsened by destructive power struggles; (ii) the lead/lag development of infrastructure and systemic imbalances in ECs, with commensurate incongruences and the absence of infrastructural synergies; (iii) the presence of sophisticated technology pockets in a sea of poor/outdated technology in ECs; (iv) the dominant presence of multinational/global, capital-strong companies, often to the detriment of local, upcoming companies that are unable to compete on an equal footing with the former, causing local resentment and resistance to their presence; (v) the existence of a young, unemployed population, alongside a severe brain drain of top talent from ECs, countered somewhat, in some instances, where strong local (multi)national companies are emerging in ECs and/or attractive entrepreneurial opportunities are germinated and nurtured that lure local talent - employed in developed countries - back to ECs; and (vi) the wide (and in many cases, widening) gap between the haves and the have-nots in ECs that creates severe ideological, socio-cultural and economic tensions and divides. The severity of the socio-cultural and economic tensions and divides may be alleviated and countered by a fast-growing middle class that many can aspire to join, alongside the emergence of rapidly expanding, resilient EC-based (multi)national companies that offer ample employment opportunities. 
At least ten major organisational and people implications can be derived from the abovediscussed EC features that are relevant to CSR for organisations with ECs as their chosen operating arenas (cf. Veldsman, 2013). These implications serve, in a concrete sense, as the macro-design specifications for contextually fit CSR that needs to frame and inform the leadership of organisations operating in ECs of these organisations' CSR stance and approach, as well as implementation thereof.

Implication 1: Adopting and infusing, as a non-negotiable vantage point, an embeddedness perspective at all times into an organisation's mindset, thinking, decisions and actions is required: "As leadership we need to take into account, at all times, the history, nature, dynamics, and trajectory of the ECs' communities/societies (the water) in which we are/ wish to operate as an organisation (the fish)" (cf. Gond \& Moon, 2012; Dobers \& Halme, 2012; Visser, 2011).

Implication 2: Given the fundamental, normative transformations that these societies are going through, with the resultant normative ambiguities and ethics (see Figure 1), a visible, clearly articulated, and well-communicated values and beliefs stance is required: "This is who we are and what we stand for". This implies having an explicit, visible, and robust organisational identity and ideology, resulting in an unambiguous ethical position, especially with respect to fraud and corruption (Dobers \& Halme, 2012; Iheriohanma, 2011; Moghalu, 2014).

Implication 3: A pro-active, well thought through stakeholder engagement strategy is required (Chandler \& Werther, 2014; Donaldson \& Preston, 2012; Freeman, 2012; Mitchell et al., 2012), because of the power struggles and ideological debates raging in these societies, involving competing, diverse and multiple stakeholders, each seeking his fair and equitable share of the cake, whatever the cake may impute. Organisations within ECs need to significantly extend their view of stakeholders (cf. Aguinis, 2011; Basu \& Palazzo, 2008; Kitzmueller \& Shimshack, 2012; Visser, 2011). The restricted shareholder perspective, conventional in Anglo-Saxon countries, is insufficient.

Implication 4: Architecting effective, pragmatic engagement mechanisms to bring the voices of different segments of the EC communities/societies into the organisations, so that these parties can be fully heard, is required. This has been called "opening up the bottom (or base) of the pyramid", first proposed by C.K. Prahalad (Dobers \& Halme, 2012; Visser, 2011). This necessitates opening up organisational boundaries so that stakeholders, internally and externally, can move effortlessly across these boundaries, enabling them to interact seamlessly with the organisation and its leadership (Visser, 2011; see Moghalu, 2014, for a more Africa-specific application at societal level).

Implication 5: Visibly and concretely demonstrating good corporate citizenship through real, sustainable leadership and societal capacity-building and upliftment interventions, addressing genuine needs and requirements in EC communities, is required. Local stakeholders need to be directly involved in real and meaningful ways by formally and informally engaging haves and have-nots, employees and non-employees, communities 
and non-government and private organisations (Broomes, 2013; Dobers \& Halme, 2012; Moghalu, 2014; Ragan et al., 2015; Visser, 2011).

Implication 6: Actively stepping in to smooth over and fill societal infrastructural underdevelopment/mismatches and systemic imbalances, enabling communities/ societies and one's own organisation to function better, e.g. improving the road or educational system, is required (Broomes, 2013; Dobers \& Halme, 2012; Moghalu, 2014).

Implication 7: Adopting a geocentric attitude (Perlmutter, 1969) by finding credible local partners with whom strong partner relationships can be formed to jointly create wealth, locally and globally, is required. In addition, local talent has to be given equal employment and career opportunities across all organisational levels/areas, locally and globally (Broomes, 2013; Dobers \& Halme, 2012; Moghalu, 2014).

Implication 8: Crafting a highly attractive, aggressive, EC-specific employee value proposition to attract, engage and retain top local EC talent and lure back EC talent that is currently abroad is required by, e.g. offering partnerships and shareholding. Being a responsible corporate citizen can also be part of an organisation's employee value proposition (Guillén \& García-Canal, 2013; Kitzmueller \& Shimshack, 2012).

Implication 9: Deploying fit-for-purpose technologies appropriate to the skills levels available in ECs, and/or offering intensive, on-going capacity-building through training/ education opportunities in order to upgrade EC employees' knowledge and skills to what is required by more sophisticated technologies. This would substantively enhance the quality and quantity of EC talent pools (Dobers \& Halme, 2012; Ragan et al., 2015; Visser, 2011).

Implication 10: The forming of joint, value-generation networks through alliances and partnerships will enable local emerging organisations to build global competitive capabilities (Broomes, 2013; Dobers \& Halme, 2012; Moghalu, 2014; Visser, 2011) By, for example, assisting them to move downstream in the beneficiation of local natural resources.

Against the backdrop of the above ten major CSR organisational and people implications for organisations with ECs as their chosen operating arenas, what, then, should be the overarching, essential, unique nature of CSR in ECs? What would make CSR different from organisations operating in ECs, and make Embedded CSR critical?

I would like to posit that this difference is to be found in a wholehearted identification with, and (pro-)active enablement by, an EC-active organisation of the radical, societal transformational journey undertaken by an EC in its aspiration to become a fully integrated, worthy, contributing and reputable world citizen (cf. Broomes, 2013; Dobers \& Halme, 2012; and Moghalu, 2014, for a case in point regarding Africa). Put differently, by becoming a genuine and trusted societal transformation partner, and not being merely a spectator, observing EC societal dynamics - admittedly, most often chaotic - in a somewhat bemused, passive and detached sense. Of course, partnering in ECs need to occur within the scope and reach of the organisation's competencies, capabilities and resources (see below). 


\section{Embedded CSR For Organisations Desiring to enter or Already Operating In EcS}

At this point in the discussion, I would like to draw the following three major conclusions from the above discussion, given my CSR vantage point of an embedded organisation, organically and systemically located within a (dis)empowering and/or (dis)enabling EC context, and being a genuine, trusted and involved societal transformation partner. These conclusions will set the scene for the discussion that follows thereafter.

Firstly, in general, Embedded CSR, as proposed by Aguinis and Glavas (2013), must be taken as a normative position - the should be of CSR - in providing the non-negotiable departure point of all organisations' CSR drives, especially within ECs, for the reasons discussed above, endorsed by, inter alia, ABländer (2011) and Büchner (2012). Thus, these authors' Embedded CSR prescriptive stance is endorsed.

Secondly, in contrast to Embedded CSR, Peripheral CSR, as suggested and observed by the above authors, is a deviation from the normative position. As stated, quite rightly, by them, such a CSR position can only be seen as self-serving window dressing, green washing, and currying favour, to the detriment of the organisation's image, reputation and legitimacy (Aguinis \& Glavas, 2013; Visser, 2011). Peripheral CSR is not true to the spirit of genuine Embedded CSR. This is particularly true of large global organisations operating in ECs, where one may even encounter actions and mobilisation from local communities in reaction to the presence of such organisations (discussed above). It would be far preferable for an EC-located organisation's image, reputation and legitimacy to openly state that it does not subscribe to CSR as a matter of strategy and policy, a stance of "the business of business is business", and then face the stakeholders' reactions, rather than to engage with CSR half-heartedly, superficially, and peripherally.

Thirdly, finding and maintaining a balanced, aligned, and integrated outside-in AND inside-out, as well as a top-down AND bottom-up, CSR perspective will make CSR truly embedded in the organisation. An outside-in approach pertains to a genuine understanding of, listening to, and reaching out to meet pressing social needs, and must be addressed in the EC communities/societies in which an organisation is embedded. An inside-out approach encompasses a deep insight into what organisational competencies, capabilities and resources are available internally that can be applied to possible CSR initiatives by the organisation with respect to its EC operating arena. A top-down approach entails CSR that is driven and role-modelled by the executive leadership of the organisation. A bottom-up approach relates to CSR involvement from the coalface upwards in the organisation, where daily interactions with stakeholders occur at the base of the pyramid. It is believed that only within this seamlessly merged and aligned CSR outside-in/inside-out, and top-down/bottom-up approach will strong, synergistic and genuinely value-adding Embedded CSR emerge.

Using the above conclusions as the framework for the discussions below, I would next like to propose five mutually supportive building blocks, depicted in Figure 2, for truly Embedded CSR, as seen from an EC perspective and an organisational leadership vantage point. The five building blocks can be regarded as sense-making tools with respect to Embedded CSR in ECs (Basu \& Palazzo, 2008). 


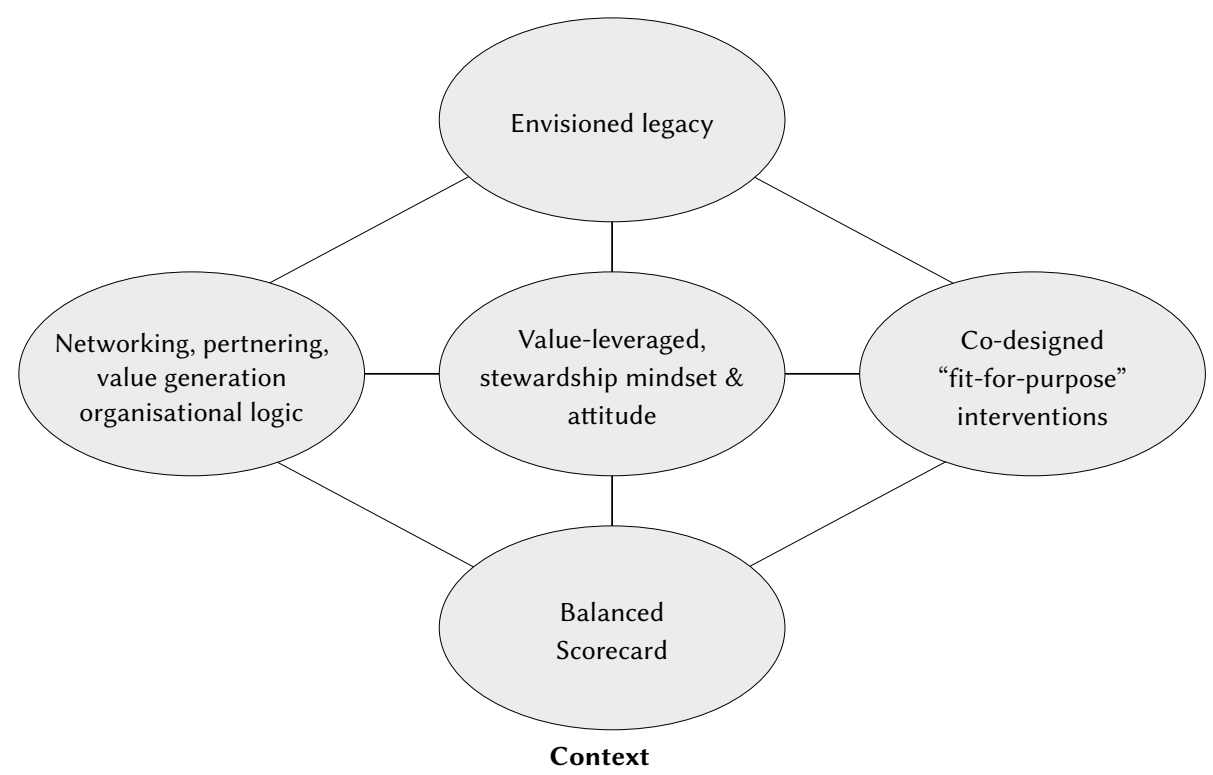

Figure 2. The mutually supportive building blocks of true and genuine Embedded CSR

Of course, the building blocks given in Figure 2 and to be discussed below could also be applicable to organisations operating in developed countries. However, my focus will be exclusively on organisations within ECs who have adopted the role of a genuine, trusted and involved societal transformation partner. Space does not allow to me to discuss whether any differences exist between the building blocks for developed countries and those for ECs, or whether such a difference is to a degree or complete. In accordance with the spirit of Aguinis and Glavas's (2013) proposed normative Embedded CSR, these building blocks can also be seen as normative guidelines informing the process of operationalising Embedded CSR in an organisation.

\section{Embedded CSR building block 1: A value-leveraged, stewardship mindset/attitude}

As per the vantage point of this article, Embedded CRS requires a steward (or servant) mindset/attitude that allows the organisation to see itself as an inherent part of the intricate fibre and DNA of the communities/societies in which they operate (Visser, 2011). They need to view themselves as acting as the trusted custodian of the assets of the communities/societies in which they are embedded and operating. In this way, an organisation will meet EC Implication 1 for Embedded CSR in ECs (see the above discussion of organisational and people implications of ECs for CSR initiatives).

Such organisations believe that the assets they have access to, control over, and are utilising have been entrusted to them, to be used in ways that, at a minimum, do not compromise the livelihood of future EC generations. Optimally, these assets should be used in ways that would leave upcoming EC generations with a better future because the organisation has contributed to transforming society (ABländer, 2011). 
Organisations with a stewardship mindset/attitude will engender abundant prosperity through the value they unlock and the wealth they create, by delivering enriching products/services. Enriching (or useful) products/services are those conceived, delivered and distributed to satisfy genuine needs in a real way for the greater good of all in the transforming society. These organisations leave their stakeholders significantly better off with their products/services, while simultaneously sharing, fairly and equitably, the wealth they are creating with the people who contribute to creating that wealth (Broomes, 2013; Dobers \& Halme, 2012).

Organisations pursuing Embedded CRS, furthermore, are caring organisations. They care about the well-being of their clients, now and in the future; the quality of the context in which they are operating; as well as about the fair and equitable sharing of wealth among the people in their organisation (ABländer, 2011; Delios, 2010). A visible, aggressively espoused, communicated and concretely demonstrated stewardship mindset/attitude from a partnering stance is essential to global organisations active in ECs, to counter the stereotype of economic re-colonisation and exploitation of ECs by these organisations (see Moghalu, 2014, for a case in point regarding Africa).

At all times, steward organisations' actions have to be infused with a sense of rightness, publicly stated as doing the right (or good) thing for the right reasons, in the right way, at the right time. They are virtuous organisations, guided by an explicit moral compass. All of their thinking, decisions, actions and the wealth they wish to unlock are based on, and leveraged from, an uncompromising, openly stated value- and norm-informed position that is morally defensible and seen not to be compromised in any way, regardless of the circumstances and the parties involved (Chandler \& Werther, 2014).

These organisations have mastered the art of building and nurturing deep, morally based relationships with stakeholders, informed by the qualities of legitimacy, fairness, and equity (Fisher \& Grant, 2012; Pless et al., 2012; Rajak, 2011). Global organisations active in EC countries, therefore, must have a clear, openly communicated value stance (with commensurate sanctions in the case of deviations), in order to prevent them from becoming entrapped in the corrupt, fraudulent and unethical practices that are rife in many ECs, and to be considered as employing the accepted way of getting things done. In this way, an organisation will realise EC Implication 2 of Embedded CSR (see above).

\section{Embedded CSR building block 2: An envisioned legacy}

Framed by a value-leveraged stewardship mindset/attitude, the imperative for an Embedded CSR-driven organisation is the leitmotiv of leaving something of genuine value behind for current and future generations - a lasting, worthy legacy. Organisations adopting Embedded CSR are infused right into their core with a burning passion to make the world a better place than the one they found. This legacy can be about improving what is, making the existing even better by extending it, changing the existing into something different, and/or bringing the completely new into being, e.g. initiatives such as GE's Ecomagination or IBM's Smarter Planet (cf. Aguinis \& Glavas, 2013), BAE's Making the world a safer place, or Standard Bank of South Africa's Bank the unbanked (Rajak, 2011). 
Such a legacy could also be framed in terms of, and derived from, international aspirations, like the UN's Global Compact, the UN's Millennium Goals, industry codes, ISO 2600 standards for social responsibility and the likes (cf. Aguinis, 2012; Broomes, 2013; Büchner, 2012; Kitzmueller \& Shimshack, 2012; Rajak, 2011; Visser, 2011). In the case of ECs, this legacy would relate to what these countries would like to look like once they have fully transformed in their endeavour to become fully integrated, worthy, contributing and reputable world citizens.

Leadership-wise, Embedded CSR-driven organisations have moved beyond "How?" (i.e. transactional) and "What?" (i.e. transformational) leadership by recasting their leadership into "Why?" leadership (i.e. transcendental or spiritual). Such leadership centres around ultimate purpose, meaning and worth. Transcendental leadership resonates with and responds to people's existential search for meaning (Frankl, 1992). Given the fundamental transformation that ECs are undergoing, in creating societal existential meaningfulness, it is imperative that Embedded CSR in ECs is meaning-giving and purposeful for all stakeholders, e.g. GE's Purposeful leadership (cf. Aguinis \& Glavas, 2013).

Embedded CSR furthermore requires that the lasting, worthy legacy is conceived and expressed in the form of a dream shared among stakeholders, an inspiring vision of what the desirable EC future will look like once the legacy has become a reality. This would provide stakeholders with a common destiny: "We are in this together." Embedded CSR organisations as transformation partners would be driven by the urgency to find and realise a shared, desirable EC future in concert with its stakeholders, and to express it in the form of an inspiring EC dream. While the legacy pertains to the desire to leave behind something of lasting value and worth: "A better world", the dream pertains to giving concrete substance to the legacy (Chandler \& Werther, 2014; Visser, 2011).

An organisation's envisioned CSR legacy needs to inform its CSR's strategic intent (Aguinis, 2011; Ganescu, 2012). Organisations active in EC countries, therefore, must co-generate, in partnership, an inspiring, context-relevant, envisioned legacy among local stakeholders that will direct and guide their joint Embedded CSR thinking, decisions and actions in those countries. In this way, these organisations will engender local stakeholders' goodwill towards their presence in the EC. They will not be seen as intruding outsiders representing a threat, or as exploiters. They will obtain a moral and ethical 'license to operate' (cf. Aguinis \& Glavas, 2013). All of the above are necessary to realise EC Implications 2, 3, and 4 of Embedded CSR in ECs, explicated earlier on.

\section{Embedded CSR building block 3: A networking, partnering, value- generating organisational delivery logic}

From a transformational partnership stance, Embedded CSR in ECs demands reinventing the organisation's delivery logic - its operating model - to create a relationshipcentric organisation able to engage intensely and seamlessly with all its stakeholders, both internally and externally (a geocentric attitude, as referred to above). For genuine Embedded CSR to be realised, stakeholders must be transformed into trusted partners 
of the organisation who, in concert with the organisation, pursue Embedded CSR value unlocking and wealth creation. In all of this, all parties involved will be directed and guided by a co-generated, shared, EC-relevant envisioned legacy (ABländer, 2011; Okoye, 2012; Matthews, 2014).

A constructive social pact must be established, with stakeholders as active, genuine partners. Partnering, as the concrete manifestation of a relationship-centric organisation, pertains to two or more individuals, groups or organisations that are able and willing to engage in a mutually beneficial, two-way Embedded CSR value-exchange - crossboundary relationships based on trust. The time perspective of Embedded CSR partnering is long term: "We are in this together for the long haul". In this way, EC Implication 10 of Embedded CSR will be realised.

This relationship-centric transformation requires a radical shift in the organisational design logic: from being a command-and-control, power-based organisation to becoming a distributed network organisation driven by Embedded CSR value creation with trusted partners, both inside and outside of the organisation (Visser, 2011). In ECs, an organisation must extend its range of stakeholders (see EC Implication 3, above). In ECs with collectivistic, national cultures, where societies partnering is a societal expectation and norm (cf. Ho et al., 2012), such stakeholder engagement becomes even more of a critical enabler in ensuring legitimate, credible Embedded CSR.

Identifying the full range of stakeholders is core in ensuring that all the "right" voices are heard at the "right" time in the organisation with respect to Embedded CSR (Pless et al., 2012; Visser, 2011), in this way realising EC Implications 3 and 4 of Embedded CSR. The choice of the right and ethical stakeholders to partner with requires careful consideration and skilful politicking, because of the ongoing power struggles and fiercely defended ideological divides in ECs, as explicated above. This would enable an organisation active in ECs to realise EC Implication 2 of Embedded CSR.

\section{Embedded CSR building block 4: A carefully co-crafted CSR strategy, translated into co-designed, fit-for-purpose CSR interventions, overseen by a dedicated CSR executive}

The earlier conclusion regarding an outside-in/inside-in and top-down/bottom-up approach to Embedded CSR necessitates the strategic matching of the pressing CSR needs specific to the communities/societies within the EC operating arena of an organisation to the organisation's internally available organisational competencies, capabilities and resources, as framed by the organisation's envisioned Embedded CSR legacy.

This strategic matching can only come about through the careful crafting of a well thought through Embedded CSR strategy - the manner in which the envisioned legacy of the embedded CSR will be realised (ABländer, 2011; Chandler \& Werther, 2014; Ganescu, 2012; Ragan et al., 2015). All partners need to be intensely involved in the crafting of such a strategy and its roll-out. In the case of a global organisation, differentiated Embedded CSR initiatives will have to be crafted across the respective ECs making up 
the organisation's operating arena, in order to give an organisation's Embedded CSR local legitimacy and traction, reinforcing the organisation's position as a genuine and trusted local societal transformation partner (cf. Ho et al., 2012; Rajak, 2011).

Given the abovementioned features of ECs, with their people and organisational implications, the contextually fit-for-purpose Embedded CSR interventions of organisations in ECs need to form a synergistic portfolio that has multiple value-adding effects on the ECs in which the organisations are active. The aim of these interventions must be to establish enhanced "can-do" capacities in the EC concerned, equipping beneficiaries in the EC to "catch fish", instead of being "given fish". The choice and range of interventions, crafted into a synergistic, high-impact portfolio of interventions, therefore, must empower EC communities and societies to help themselves. This implies a trend-breaking shift from aid to investment. In this way, EC Implications 5 to 10 of Embedded CSR will be realised (Dobers \& Halme, 2012; Moghalu, 2014).

Five interdependent categories of Embedded CSR interventions can be distinguished, making up an organisation's Embedded CSR portfolio of interventions within the EC concerned (cf. Aguinis \& Glavas, 2013; Broomes, 2013; Fisher \& Grant, 2012; Okoye, 2012; Pless et al., 2012; Ragan et al., 2015; Rajak, 2011; Visser, 2011).

(i) Ethical and governance interventions: pursuing and engendering globally accepted standards regarding corporate governance, employment relations, working conditions and the environment, propagated by the likes of the United Nations and the International Labour Organisation;

(ii) Community/societal interventions: reducing the organisation's environmental impact, enabling communities/societies to function more effectively and efficiently by smoothing over and filling infrastructural underdevelopment/mismatches and systemic imbalances, e.g., making energy supply more predictable or reducing traffic congestion, such as in the case of IBM (cf. Aguinis \& Glavas, 2013);

(iii) People interventions: enhancing the quality of local talent (both employed and unemployed) in terms of academic and/or vocational competencies and job experience, by matching these to local/global talent demands;

(iv) Organisational interventions: assisting in building the necessary competitive capabilities in local organisations, to enable them to compete more effectively, by, for example, incorporating them as genuine business partners in the organisation's supply chain, and by capacitating them to enter into and compete successfully in the global village; and

(v) Leadership interventions: building the necessary leadership capability in communities/ societies, in this way equipping persons to constructively lead their communities/ societies through fundamental transition and transformation. These leaders need to be able to utilise and deploy the capabilities resulting from the other four enabling intervention categories. 
The categories of interventions making up the Embedded CSR portfolio of an organisation are a direct function of its leadership's responsibility orientation (already alluded to in the introduction) (Pless et al., 2012), how they make sense of CSR (Basu \& Palazzo, 2008), and their motives for CSR (Graafland et al., 2012). The leadership responsibility orientation is influenced, inter alia, by contextual dimensions, with their commensurate stakeholders, as acknowledged by the organisation's leadership.

The CSR strategising process and its outcomes, as well as the envisioned legacy and the commensurate strategy of the CSR, with its consequential implementation through a portfolio of CSR interventions, have to be the responsibility of a C-suite executive. The presence of Embedded CSR in the executive suite will give the CSR of the organisation the necessary high-level organisational attention and the stature it deserves (Aguinis, 2012; Ragan et al., 2015; Strand, 2013; Matthews, 2014). Embedded CSR now becomes an inherent, essential element of an organisation's overall strategic intent, e.g. Intel's Enrichment of the lives of every person on earth (cf. Aguinis, \& Glavas, 2013; Ganescu, 2012). CSR will be on the organisation's strategic radar and agenda. In this way, CSR truly becomes embedded. Appointing country-dedicated CSR leaders will be missioncritical if an organisation is serious about its societal transformation partnering role. In this way, CSR will have a local, ongoing presence, enabling the building of strong incountry partnerships, which will allow for fit-for-purpose local interventions (cf. Dobers \& Halme, 2012; Visser, 2011).

\section{Embedded CSR building block 5: An embedded CSR balanced scorecard}

An organisation's Embedded CSR performance must be defined, tracked and assessed in a holistic, integrated and systemic manner (Aguinis, 2012; Basu \& Palazzo, 2008; Pless et al., 2012; Prasertsang et al., 2012; Ragan et al., 2015; Van Marrewijk \& Hardjono, 2003), relative and linked to the organisational strategy it is pursuing (Burke \& Logsdon, 2012; Chandler \& Werther, 2014).

Using a balanced scorecard approach (cf. Kaplan \& Norton, 1992), Figure 3 gives a graphic view of a suggested Embedded CSR performance measurement model, with four interdependent performance dimensions and possible measures by which the Embedded CSR performance of an organisation can be adjudged (see also Aguinis, 2011; Aguinis \& Glavas, 2013; Chitakornkijsil, 2012). Incorporated into this balanced scorecard is the triple bottom line of economic (= profit), social (= people), and environmental performance (= planet) (cf. Aguinis, 2011; Broomes, 2013; Graafland et al., 2012; Kitzmueller \& Shimshack, 2012).

The Embedded SCR balanced scorecard of an organisation must not only be aligned to the strategic intent of the organisation (Aguinis, 2011), but must reflect the reasons why the organisation is undertaking Embedded CSR (Basu \& Palazzo, 2008). Furthermore, to be truly Embedded CSR-driven, these measures must be included as key performance areas/indicators (KPAs/KPIs) in the individual performance contracts of organisational members at all levels. 


\section{Benefit Realisation}

- Citizen satisfaction: \% citizens believing they are living better lives because of product/service and its delivery by organisation

- Monetary value of eco-friendly products/services as \% of local revenue/market share

- $\%$ local revenue co-generated with local partners

- Employee fairness: Ratio of local employee rewards to local company

- revenue; Ratio of local employee rewards to local company revenue growth

- Local employee rewards as \% of local company revenue

- $\%$ reduction in local environmental impact

- CSR spent as percentage of local company revenue

- CSR expenditure as percentage of local employee cost to company

- Investment in community infrastructure as \% of local company revenue/market share

\section{Stakeholder Credibility \& Legitimacy}

- Citizen satisfaction: \% citizens believing they are living better lives because of product/service and its delivery by organisation

- Monetary value of eco-friendly products/services as \% of local revenue/market share

- \% local revenue co-generated with local partners

- Employee fairness: Ratio of local employee rewards to local company

- revenue; Ratio of local employee rewards to local company revenue growth

- Local employee rewards as \% of local company revenue

- \% reduction in local environmental impact

- CSR spent as percentage of local company revenue

- CSR expenditure as percentage of local employee cost to company

- Investment in community infrastructure as \% of local company revenue/market share

\section{Envisioned Legacy}

\section{Capacity Building}

- Talent Abundance: \% successors identified from local employees for critical posts; Percentage vacancies filled from local internal employees

- People Investment: Training \& development days per full time equivalent local employee; Training and development investment as \% of salary bill

- People Growth: Percentage of local employees fulfilling their Personal Development Plans

- New Talent: \% local interns placed; local talent as $\%$ of total talent appointed in country

- $\quad$ Learning \& development effectiveness: \% local programmes achieving high importance and improvement ratings

\section{Internal Organisational State}

- Employee engagement/commitment: \% engaged/ committed employees, especially local employees

- Quality of local employee-employer relationships, especially local employees

- Person-job coherence and meaningfulness fit

- Organisational/ job identification

- \% employees involved in CSR interventions

- \% CSR proposals submitted and implemented per full-time equivalent local employee

- In country \% improvement in health and safety of employees

- Sustainable utilisation of local natural resources

- Meeting international core labour standards locally

- Meeting international corporate governance standards locally

Figure 3. An Embedded CSR balanced scorecard

A deep and widely shared understanding must be cultivated in the organisation about the dynamic interplay between the different Embedded CSR performance dimensions being tracked and assessed (i.e. the evolving, dynamic big picture). In this way, a highlevel, interactive Embedded CSR model of the interdependencies of Embedded CSR variables can be empirically established.

The insights gained need to be used to direct and guide an ongoing, real-time dialogue between partners about the organisation's Embedded CSR performance, where the CSR foci need to be, and what action needs to be taken to bring about enhanced/expanded 
CSR performance. Embedded CSR then becomes “intelligence-driven”. Because of the required strategic perspective of genuine Embedded CSR, it will be important to track and assess CSR performance over the long term, and not focus on the short term, e.g. this quarter's or year's CSR performance.

In summary: the five mutually supportive building blocks (see Figure 2) of true Embedded CSR as applicable to ECs, given that the organisation in the EC is a genuine, trusted and involved societal transformation partner, then are: a value-leveraged stewardship mindset/attitude; an envisioned legacy; a networking, partnering, value-generating, organisational delivery logic; a carefully co-crafted Embedded CSR strategy, translated into a co-designed, fit-for-purpose portfolio of CSR interventions, overseen by a dedicated CSR executive; and the use of an Embedded CSR balanced scorecard, in order to make the CSR intelligence-driven.

\section{Conclusion}

Without any doubt, involvement by organisations (the fish) in ECs imposes the imperative of Embedded CSR in order to establish and maintain a legitimate and credible presence and image of organisations as value-adding contributors in these countries (the water).

It was argued that the overarching, essential, unique nature of Embedded CSR in ECs is to be found in a wholehearted identification with and (pro-)active enablement of the EC by the organisation, in the radical, societal transformational journey undertaken by an EC in the EC country's aspiration to become a fully integrated, worthy, contributing and reputable world citizen. This implies that organisations active in ECs should become and be genuine and trusted societal transformation partners in the ECs concerned, within the constraints of resources and capabilities. This requires a strong identification by such organisations with the aspirations of the countries falling within their operating arenas.

Given this EC-unique transformational, partnering role, the question that can be posed in the final instance is whether the term corporate social responsibility is appropriate to the EC context. Does the term not signify, at face value, merely that an organisation will act responsibly - do no harm, i.e. be, at least, compliant, or, at most, only do good? Would not doing harm and/or doing good really save the day for ECs that are on the challenging and stressful journey of societal transformation?

As argued above, I would like to contend that even Embedded CSR that is fully engrained into the DNA of an organisation - the organisation being truly sincere about the its role in and for society - entails more than only acting compliantly and responsibly in a passive way, i.e. being merely a spectator. It implies doing more than good; being more than just compliant. Should the appropriate term for CSR, even Embedded CSR, in ECs then not rather be "Societal Transformation Investment" (STI) - an active organisational engagement driven by the meaning-giving need to leave the world, in general, and, more specifically, the EC concerned, the desirable place it aspires to be. Overall, the aim should be actively partnering with stakeholders in ECs to significantly increase the likelihood of a successful societal transformation journey, in order to turn such countries into fullyfledged, value-creating, and wealth-contributing world citizens. 
Such partnering would imply, inter alia, a long-term commitment, a clear value and ideological stance, significant resource and capacity allocations, an executive leadership focus, and a comprehensive portfolio of real change-effecting, intense Embedded CSR interventions by the organisation. Would the proposed term STI not be more reflective of the true strategic, transformational Embedded CSR partnering intention of EC-based organisations through sharing the dreams of the countries in which they are active?

\section{Acknowledgement}

Insights gained from valuable comments by anonymous reviewers are gratefully acknowledged.

\section{References}

ABländer, M.S. 2011. Corporate social responsibility as subsidiary co-responsibility: A macroeconomic perspective. Journal of Business Ethics, 99(1): 115-128.

Agbakoba, J.C. 2004. Transitional African political thought and the crises of governance in contemporary African societies. Journal for the Study of Religions and Ideologies, 3(7): 137-154.

Aguinis, H. 2011. Organisational responsibility: Doing good and doing well (pp. 855-879). In: Zeldeck, S. (Ed.). APA Handbook of Industrial and Organisational Psychology, Vol 3: Maintaining, expanding and contracting the organisation. Washington: American Psychological Association.

Aguinis, H. \& Glavas, A. 2013. Embedded versus peripheral social responsibility: Psychological foundations. Industrial and Organisational Psychology: Perspectives on Science and Practice, 6(4): 314-332.

Basu, K. \& Palazzo, G. 2008. Corporate social responsibility: a process of sensemaking. Academy of Management, 33(1): 122-136.

Benedict, O.H. \& Ukpere, W.I. 2012. Brain drain and African development: Any possible gain from the drain? African Journal of Business Management, 6(7): 2421-2428.

Bernstein, A. 2010. The case for business in developing countries. Johannesburg: Penguin Books.

Blas, J. \& England, A. 2014. Investors keep an eye on the big picture in Africa. Sunday Times Business Times, 28 December: 24.

Broomes, V. 2013. Enhancing impact of CSR on economic development and livelihoods in developing countries. In: Haynes, K., Murray, A. \& Dillard, J. (Eds.). Corporate social responsibility. A research handbook. New York: Routledge.

Büchner, L.M. 2012. Corporate social responsibility and sustainability from a global, European and corporate perspective. Corporate social responsibility and sustainable governance. Eurolimes 2012(13): 41-55.

Burke, L. \& Logsdon, J.M. 2012. How corporate social responsibility pays off (pp. 303-314). In: Gond, J-P. \& Moon, J. (Eds.). Corporate social responsibility. Critical perspectives on business and management (Vol II). London: Routledge.

Chandler, D. \& Werther, W.B. 2014. Strategic corporate social responsibility. Los Angeles: Sage.

Chironga, M., Leke, A., Lund, S. \& Van Wamelen, A. 2011. The Globe: Cracking the next growth market: Africa. Harvard Business Review, May: 177-122.

Chitakornkijsil, P. 2012. Business performing social responsibility activities and corporate social responsibility issues. International Journal of Organisational Innovation, 5(1): 309-323.

Delios, A. 2010. How can organisations be competitive but dare to care? Academy of Management Perspectives, 24(3): 25-36.

Dobers, P. \& Halme, M. 2012. Corporate social responsibility and developing countries (pp. 174-193). In: Gond, J-P. \& Moon, J. (Eds.). Corporate social responsibility. Critical perspectives on business and management (Vol III). London: Routledge. 
Doh, J.P., Smith, R.R., Stumpf, S.A., Tymon, W.G. \& Walter, G. 2011. Pride and professionals: Retaining talent in emerging economies. Journal of Business Strategy, 32(5): 35-42.

Donaldson, T. \& Preston, L.E. 2012. The stakeholder theory of the corporation: concepts, evidence, and implications (pp. 16-42). In: Gond, J-P. \& Moon, J. (Eds.). Corporate social responsibility. Critical perspectives on business and management ( $\mathrm{Vol} \mathrm{II})$. London: Routledge.

Ernst \& Young. 2009. Global trends 2009. Cleveland: EYGM Ltd.

Frankl, V.E. 1992. Man's search for meaning: An introduction to logotherapy. Boston, MA: Beacon Press.

Fisher, J. \& Grant, B. 2012. Beyond corporate social responsibility: Public value and the business of politics. International Journal of Business and Management, 7(7): 2-14.

Freeman, R.E. 2012. A stakeholder theory of the modern corporation (pp. 3-15). In: Gond, J-P. \& Moon, J. (Eds.). Corporate social responsibility. Critical perspectives on business and management (Vol II). London: Routledge.

Ganescu, M.C. 2012. Corporate social responsibility: A strategy to create and consolidate sustainable businesses. Theoretical and Applied Economics, xix, 11(576): 91-106.

Geldenhuys, C.A. \& Veldsman, T.H. 2010. A change navigation-based, scenario planning process within a developing world context from an Afro-centric leadership perspective. SA Journal of Human Resource Management, 9(1): 1-17.

Gond, J-P. \& Moon, J. 2012. Introduction. Corporate social responsibility in retrospect and prospect (pp. 1-22). In: Gond, J-P. \& Moon, J. (Eds.). Corporate social responsibility. Critical perspectives on business and management ( $\mathrm{Vol} \mathrm{I})$. London: Routledge.

Graafland, J., Mazereeuw, C. \& Van der Duijn, S. 2012. Motives for corporate social responsibility. De Economist, 160: 377-396.

Guillén, M. \& García-Canal, E. 2013. Emerging markets rule. Growth strategies of the new global giants. New York: McGraw-Hill.

Ho, F.N., Wang, H.D. \& Vitell, S.J. 2012. A global analysis of corporate social performance: The effects of cultural and geographical environments. Journal of Business Ethics, 107: 423-433.

IBM Global Business Services. 2008. The enterprise of the future. IBM global CEO study. Somers, NY: IBM.

Iheriohanma, E.B.J. 2011. Capacity building, leadership question and drains of corruption in Africa: A theoretical discourse. Asian Social Science, 7(3): 131-138.

Kaplan, R.S. \& Norton, D.P. 1992. The balanced scorecard - measures that drive performance. Harvard Business Review, January-February 1992: 71-79.

Kitzmueller, M. \& Shimshack, J. 2012. Economic perspectives on corporate social responsibility. Journal of Economic Literature, 50(1): 51-84.

Matthews, M. 2014. 18 July. Social investment must be real. Business Day, 18 July: 10.

Mitchell, R.K, Agle, B.R. \& Wood, D.J. 2012. Towards a theory of stakeholder identification and salience: defining the principle of who and what really counts (pp. 43-78). In: Gond, J-P. \& Moon, J. (Eds.). Corporate social responsibility. Critical perspectives on business and management (Vol II). London: Routledge.

Moghalu, K.D. 2014. Emerging Africa. How the global economy's 'last frontier' can proposer and matter. London: Penguin Books.

Okoye, A. 2012. Exploring the relationship between corporate social responsibility, law and development in an African context. Should government be responsible for ensuring corporate responsibility? International Journal of Law and Management, 54(5): 364-378.

Perlmutter, H. 1969. The tortuous evolution of the multi-national corporation. Columbia Journal of World Business, January/February: 9-18.

Pless, N.M., Maak, T. \& Waldman, D.A. 2012. Different approaches toward doing the right thing: Mapping the responsibility orientations of leaders. Academy of Management Perspectives, 26(4): 51-65. 
Prasertsang, S., Ussahawanitchakit, P. \& Jhundra-indra, P. 2012. Corporate social responsibility effectiveness, firm competitiveness, business successes and corporate sustainability: An empirical investigation of ISO 14000 businesses in Thailand. International Journal of Business Strategy, 12(4): 137-164.

Ragan, K. Chase, L. \& Karim, S. 2015. The truth about CSR. Harvard Business Review. January-February: 40-49.

Rajak, D. 2011. In good company. An anatomy of corporate social responsibility. Stanford: Stanford University Press.

Ready, D.A., Hill, L.A. \& Conger, J.A. 2008. Winning the race for talent in emerging markets. Harvard Business Review, November: 2-10.

Sachs, J. 2011. The price of civilization. Economics and ethics after the fall. London: The Bodley Head.

Schwartz, J. \& DiMarzio, M. 2011. Human capital trends 2011. Revolution/Evolution. Deloitte Consulting LLP.

Shah, J.I. 2011. Brain drain: Why people leave their motherland? (Implications for the developed and developing economies). Journal of Managerial Sciences, v(1): 63-74.

Smit, F. 2011. Spieëlbeeld van die wêreld: SA volg tendense, maar kan dit die uitdagings oorkom?, Beeld, 12 July: 13.

Stone, D.L., Canedo, J.C. \& Tzafrir, S. 2013. The symbiotic relation between organisations and society. Journal of Managerial Psychology, 28(5): 432-451.

Strand, R. 2013. The Chief Officer of Corporate Social Responsibility: a study of its presence in top management teams. Journal of Business Ethics, 112: 721-734.

The Economist. 2008, 19 January. Just good business: a survey of corporate social responsibility.

The Economist. 2010, 17 April. Special report: The world turned upside down.

The Economist. 2011, 3 December. Briefing. Africa's hopeful economies.

Thirlwall, A.P. 2011. Economics of development. Theory and evidence. Houndsmills: Palgrave Macmillian.

Thite, M., Wilkinson, A. \& Shah, D. 2012. Internationalization and HRM strategies across subsidiaries in multinational corporations from emerging economies - A conceptual framework. Journal of World Business, 47(2): 251-258.

Ukpere, W.I. 2011. Globalisation and the challenges of unemployment, income inequality and poverty in Africa. African Journal of Business Management, 5(15): 6072-6084.

Van Marrewijk, M. \& Hardjono, T.W. 2003. European corporate sustainability framework for managing complexity and corporate transformation. Journal of Business Ethics, 44: 121-132.

Van Zyl, A. 2010. Opkomende lande is die sentrum van toekomstige ekonomiese groei.. Sakebeeld, 4 June: 1

Veldsman, T.H. 2008. People management in the new order. In pursuit of leading world class practices (Part 1). Management Today, 24(8): 56-60.

Veldsman, T.H. 2013. People professionals fit for emerging economies. In: Bluen, S. (Ed.). Talent management in emerging markets. Johannesburg: Knowres, 179-202.

Visser, W. 2011. The age of responsibility. CSR 2.0 and the new DNA of business. Chichester: John Wiley. 